\title{
СУБСТАНТИВНІ ФРАЗЕОЛОГІЗМИ НА ПОЗНАЧЕННЯ ЛЮДИНИ В ЛІНГВОКУЛЬТУРОЛОГІЙНОМУ АСПЕКТІ
}

\section{Гарбера I. B.}

\section{ВСТУП}

Лінгвокультурологійний підхід у фразеології грунтований на тезі про те, що культура втілює свій ціннісний зміст у мові як найбільш універсальному засобі репрезентації світу (саме мова зберігає i транслює культурні цінності). Він має на меті виявлення механізмів, способів і засобів утілення «мови» культури у змісті фразеологізмів. Лінгвокультурологійний аспект дослідження фразеологізму дозволяє зрозуміти його своєрідність як мовного знака й описати роль фразеології в категоризації культурної концептосфери. Дослідження специфіки фразеологізмів як знаків мови і культури нині актуальне, адже $\epsilon$ нагальна потреба виявити, як в образі фразеологізму виражені ті чи ті культурні смисли, як збережені їхні мотиваційні джерела.

Завдання дослідження: вивчити процес культурної інтерпретації носієм мови фразеологізмів як референції мовного знака до предметної області культури; описати систему найбільш поширених кодів культури як модель, інструмент лінгвокультурологійного дослідження фразеологізмів та як спосіб організації культурного простору (через співвіднесення компонентів фразеологізмів із кодами культури); проаналізувати механізми співіснування у фразеологічному знаку власне мовної та культурної семантики; вивчити символьність у семантиці фразеологізмів.

Для студіювання було використано лінгвокультурологійний метод, що дає можливість комплексно описати мовну й культурну семантику фразеологізму, змоделювати ті процеси, які відбуваються за вживання фразеологізму в мовленні, виявити особливості його знакової функції.

Матеріал дослідження - субстантивні фразеологізми будови «прикметник + іменник», що описують людину.

\section{1. Суть лінгвокультурологійного аспекту дослідження антропоцентричної фразеології}

Лінгвокультурологія досліджує взаємодію мови й культури в діапазоні культурно-національної самосвідомості та ii мовної презентації, вивчає національний менталітет, що знаходить вияв в 
образах довкілля, відображених у фразеологізмах. Мета лінгвокультурологійного напряму у фразеології - виявити у фразеологізмах як мовних знаках репертуар утілених у їх змісті та формі культурних смислів, виокремити ті засоби й способи, на основі яких можлива інтерпретація фразеологізмів у контексті культури, i на цій основі визначити їхню роль як знаків «мови» культури (В. Телія). Предметна область лінгвокультурології - сфера взаємодії культури та природної мови, свідомості й мови. Вона орієнтована на максимальну експлікацію процесів, що відбуваються під час відтворення та сприйняття фразеологізмів.

У лінгвокультурологійному аспекті фразеологізм витлумачують як особливий мовний знак, у семантику якого вплетені культурні смисли (культурна конотація), створювані референцією фразеологізму до предметної області культури. Культурна інтерпретація (різні форми повсякденного практичного використання й усвідомлення фразеологізмів носіями мови й культури) об'єднує мовну семантику й культурну конотацію фразеологізму, формуючи унікальне, властиве лише йому, синтезоване культурно-мовне значення. Культура водночас - простір культурних смислів, ціннісного змісту, формованого людиною у процесі світосприйняття; коди культури вторинна знакова система, яка використовує різні засоби для репрезентації зазначених культурних смислів; картина світу, що розкриває світогляд соціуму, - різними способами закодований ціннісний зміст, вироблений у культурі. Найбільш універсальним, базовим постає такий код, як мова. Саме у природній мові культура віднаходить знаки для втілення своїх смислів, що мають ціннісний зміст. Мова - оптимальний засіб вираження культурних смислів, що сприяє їх збереженню та трансляції. Так, культура перетворює знаки вербального коду на знаки вербального коду культури.

Фразеологізми - такі вербальні знаки культури, які виступають найбільш важливим об’єктом лінгвокультурології, що багато в чому пояснюване сукупністю виконуваних ними функцій. Специфіка знакової функції фразеологічної одиниці зумовлена іiі образністю. Фразеологізм будується на основі метафори, таким чином належачи до сфери творчої свідомості, що передбачає зіставлення незіставлюваного, створення приблизної тотожності, тобто ірраціональне моделювання. Створення відповідності між об’єктивною реальністю та мовним знаком (фразеологізмом) має тропеїчний характер: пара взаємно незіставлюваних значущих елементів, між якими встановлюються відношення адекватності, утворюють семантичний троп, що лежить в основі внутрішньої форми фразеологізму. Образ фразеологізму постає тим своєрідним провідником культури, завдяки якому відбувається 
взаємопроникнення двох семіотичних систем - мови й культури. Образно-мотиваційний компонент фразеологізму у процесі його інтерпретації у просторі культури спричинює появу культурної конотації фразеологізму. Фразеологізм як мовний знак зароджується в місці перетину мови й культури. В основу внутрішньої форми фразеологізму потрапляють уже окультурені сутності, які пов'язуються 3 образністю фразеологізму та його семантикою. Саме 3 комбінації кодів культури з їхнім ціннісним змістом виникає тропеїчна сутність фразеологізму: вона акумулює в собі та транслює за вживання фразеологізму культурні смисли, вплетені в його семантику. Відтворення фразеологізму зумовлено його культурною функцією він $є$ засобом збереження й передачі культурної інформації про людину й світ; фразеологізм «прийшов» у мову з культури, яка таким чином «здійснює пам'ять про себе» (Ю. Лотман). Фразеологізм як знак вторинної семіотизації виконує функцію символізації (еталонізації, стереотипізації) світу. Створений у культурі, фразеологізм здатний втілювати в собі стійкі символічні (еталонні, стереотипні) смисли, які були закладені в мовну семантику фразеологізму під час його створення, слугують культурною основою цієї семантики та «виймаються» 3 неї в мовленні. У цій особливій, культурній, функції, фразеологізм є вербалізованим символом (еталоном, стереотипом). Комунікативна функція фразеологізму формується в культурі та визначається культурною конотацією цього мовного знака. Вибір у культурі завжди мотивований (Ю. Степанов), і вибір фразеологізмів у комунікації з метою створення мовленнєвого акту є усвідомлюваним та мотивованим насамперед культурною семантикою фразеологізму. Фразеологізм - знак природної мови, замісницька функція якого визначена тропеїчною природою його внутрішньої форми (образністю), а також його проміжним становищем між лексичним і синтаксичним рівнями мовної системи.

Як початок лінгвокультурологійного етапу у фразеології визначена розробка В. Телія інтерпретаційної моделі фразеологічного значення. Згідно із цією моделлю, за допомогою фразеологізму комуніканти 1) обмінюються денотативною інформацією про предмети, явища, події реальної дійсності; 2) повідомляють і сприймають оцінку предметів, явищ, подій довкілля; 3) отримують враження від образу, що лежить в основі внутрішньої форми фразеологізму та являє собою мотивацію (основу для уподібнення) у процесі опису предметів, явищ, подій реальної дійсності; 4) відчувають емоцію щодо сказаного / почутого. Отже, у процесі лінгвокультурологійного аналізу з кожного фразеологізму можна «витягнути» різні типи інформації та здійснювати з ними ментальні операції: денотативну, оцінну, образно-мотиваційну, 
емотивну. У дослідженні ми використовуємо цю модель як робочу, аналізуючи різні типи інформації, репрезентовані студійованими фразеологічними одиницями: образно-мотиваційну (подаючи первинне, словникове значення лексеми-показника того чи того коду культури, що лежить в основі творення фразеологізму); денотативну (вивчаючи мовну семантику фразеологізму); емоційно-оцінну (представляючи контекст уживання фразеологізму 3 паралельним визначенням характеру висловлюваної комунікантами оцінки).

Інструментом, засобом лінгвокультурологійного дослідження фразеологізмів визначено систему кодів культури. В. Телія описує коди культури як вторинні знакові системи, що використовують матеріальні й формальні засоби для кодування однакового змісту, які й утворюють картину світу, менталітет певного суспільства ${ }^{1}$. В. Красних порівнює коди 3 «мережею», яку людина «накидає» на довкілля, членуючи, категоризуючи, структуруючи й оцінюючи його ${ }^{2}$. О. Селіванова інтерпретує коди культури як мережу членування, категоризації, оцінок інтеріоризованого світу та внутрішнього досвіду людини, зумовлену культурою певного суспільства й репрезентовану в семіотичних системах природної мови, мистецтва, обрядів, звичаїв, вірувань, у нормах моралі, поведінці членів етнічної спільноти ${ }^{3}$. Ф. Бацевич зазначає, що коди культури - це «сукупність знаків (символів) та їх смислів, котрі наявні в будь-якому предметі культури певної національної лінгвокультурної спільноти; знаходить вияв також в етнічній мові, мовній картині світу» ${ }^{4}$. О. Березович розглядає коди культури як «знаряддя для вираження смислів, що мають різні формальні «обличчя»» ${ }^{5}$. Д. Гудков і М. Ковшова визначають коди культури як семіотичну систему для кодування певного культурного змісту: це «система знаків матеріального та духовного світу, які стали носіями культурних смислів» ${ }^{6}$ Р Реалізуються коди культури здебільшого на мовному матеріалі. Л. Савченко стверджує, що код

Телия В. Русская фразеология. Семантический, прагматический и лингвокультурологический аспекты. Москва, 1996. 286 с.

2 Красных В. Этнопсихолингвистика и лингвокультурология : курс лекций. Москва, 2002. 284 с.

3 Селіванова О. Нариси з української фразеології (психокогнітивний та етнокультурний аспекти). Київ ; Черкаси, 2004. 276 с.

${ }_{5}^{4}$ Бацевич Ф. Словник термінів міжкультурної комунікації. Київ, 2007. 205 с.

5 Березович Е. Язык и традиционная культура: этнолингвистические исследования. Москва, 2007. 600 с.

${ }^{6}$ Гудков Д. Единицы кодов культуры: проблемы семантики. Язык. Сознание. Коммуникация. Москва, 2004. Вып. 26. С. 39-50 ; Ковшова М. Семантика и прагматика фразеологизмов: лингвокультурологический аспект : автореф. дис. ... докт. филол. наук: 10.02.19. Москва, 2009. 48 с. 
культури - «це відповідна національна етнокультурна інформація, що кодується у формі, здатній ідентифікувати культуру, через сукупність вторинних знаків і символів, наділених такими смислами (та їх комбінаціями), які можуть проявлятися в предметах матеріальної i духовної діяльності людини на рівні семіотичного простору». «Культура етносу створюється і формується, передається і зберігається, трансформуючись через код. Код $є$ своєрідним інструментом доступу до базових елементів культури, що наявні в будь-якому предметі діяльності людини». Погоджуючись із тим, що основний засіб вираження кодів культури - різноманітний етнічно маркований мовний матеріал, дослідниця розглядає саме фразеологізми як особливі «згорнуті» мікротексти, чиї компоненти й образи пронизані кодами культури, здатні зберігати й передавати культурну інформацію. Фразеологізми - самі собою специфічна семіотична система, адже акумулюють стереотипні уявлення народу, репрезентуючи в особливих вербальних формах його бачення людини, іiі характеру, зовнішності, властивостей поведінки тощо. Уявлення ці глибоко вкорінені в свідомості кожного носія мови, який використовує фразеологізми в процесі спілкування. Код культури демонструє двобічний зв'язок між означуваним предметом чи явищем та уявленням людини про них. За твердженням Л. Савченко, компоненти, образи, семантика фразеологізму безпосередньо співвідносяться 3 індексами кодів. Крім того, спільність виявляється й у механізмі їх виникнення - явищі метафоризації (явище культури ↔ код ↔ фразеологізм): коди культури пов'язані із фразеологією через метафору. Отже, під кодом культури в дослідженні розуміємо вторинну знакову систему, що структурує, категоризує, оцінює матеріальний i духовний світи людини й репрезентована різними етнокультурно маркованими мовними одиницями (у межах роботи - фразеологізмами $)^{7}$.

Дослідження показало, що ключовими для опису антропоцентричної субстантивної фразеології постають соматичний (моделює образи частин тіла людини (рідше - тварини) і продуктів іiі життєдіяльності), зооморфний (моделює образи тварин, земноводних, птахів, комах), антропний (моделює образи номінацій людини) та міфологічний (моделює образи релігійних і надприродних уявлень, героїв міфів, казок, легенд, літературних творів) коди культури (далі - КК).

\footnotetext{
${ }^{7}$ Савченко Л. Феномен етнокодів духовної культури у фразеології української мови: етимологічний та етнолінгвістичний аспекти. Сімферополь, 2013. 600 с.
} 


\section{2. Соматичний код культури в антропоцентричній фразеології - ядро вторинної семіотичної системи}

Цей КК (пор. соматичний - у працях Р. Батсурена, Ф. Бацевича, О. Галинської, М. Ковшової, О. Селіванової, Н. Скоробагатько, I. Чибор; соматичний (тілесний) - у працях В. Красних, Л. Савченко; фізіологічно-соматичний - у працях Т. Леонтьєвої; антропоморфний у працях Г. Багаутдінової, М. Піменової, І. Токаревої) моделює образи частин тіла людини / тварини та продуктів іiі життєдіяльності. Найпродуктивнішим репрезентантом соматичного КК у фразеології, яка описує людину, є лексема «голова», що втілює образномотиваційний грунт творення фразеологічних одиниць і реалізує у структурі їхньої семантики такі прямі словникові значення: «частина тіла людини або тварини, у якій міститься мозок - вищий відділ центральної нервової системи», «частина тіла людини як орган мислення; мозок». Денотативна інформація, яку несуть ці фразеологічні одиниці, також реалізована в їхньому значенні, а емоційно-оцінна - у контексті їх уживання. Так, фразеологізми 3 компонентом «голова» описують розумові здібності людини: 1) у негативному ключі - розумово обмежену, 3 низьким рівнем інтелектуального розвитку: дубова голова (про розумово обмежену, тупу людину) - Плювать мені на їхнє схиляння, я тільки хочу довести, вселити в ӥхні дубові голови, щуо я інший, не такий, як вони, й маю право ходити, по терехівському Хрещатику з руками за спиною <...> (Володимир Дрозд, «Катастрофа»); дурна голова (нерозумна, некмітлива, нетямуща людина) - От, мовляв, дурна голова, знайшов новину, яку розумні люди відкрили ще за сотні літ перед ним (Юрій Смолич, «Прекрасні катастрофи»); капустяна голова (про некмітливу, нерозторопну, неуважну людину) - I чому не міг у своїи капустяній голові знайти крихітку чемності, але відразу підвівся на задні лаби, як подразнений медвідь? (Іван Франко, «Для домашнього огнища»); куряча голова (про некмітливу, нерозторопну, неуважну людину) - Ви гадаєте, ия дівчинка може держати в своїй курячій голові всі иі речі <..> (Олександр Довженко, «Прощай, Америко!»); нерозумна голова (про некмітливу, нетямушу людину) - Мати он як клопочеться нею, он як хоче застерегти від осмути, біди-безліття, а доня те й робить, щуо суне, куди не слід, свою нерозумну голову, сама на себе недолю кличе (Дмитро Міщенко, «Синьоока Тивер»); порожня голова (про нерозумну, нетямущу людину) - Дурна, з порожнььюю головою, ще й опришкувата та вередлива (Іван Нечуй-Левицький, «Неоднаковими стежками»); пуста голова (нерозумна, нетямуща людина) - I я, пуста голова, навіть не подумав, яке лихо могло спіткати того дуба, $i$ побіг за Любою (Михайло Стельмах, 
«Щедрий вечір»); 2) у позитивному ключі - розумово розвинену, 3 високим рівнем інтелектуального розвитку: золота голова (про здібну, обдаровану людину) - Казав я тобі, Максиме: золота голова в нашого пана Івана (Юрій Сорока, «Іван Богун»); розумна голова (про розсудливу, кмітливу, тямущу людину) - Може, ї̈ розумна голова виносила б вердикти доброти і справедливості (Ірина Савка, «Осиний мед дикий»); світла голова (дуже розумна людина) - I Плеханов, розумник, світла голова, справжній марксист, єдиний, хто міг заперечити Леніну $i$ кого Ленін міг послухатися, не подав руки Савинкову (Ростислав Самбук, «Останній заколот»); твереза голова (про розсудливу, кмітливу, тямущу людину) - I все ж зупинився 6 останній момент, примусив себе зупинитися - сам би зневажав себе за цей порив гніву, бо знав, що йому $i$ його підлеглим гнів може лише пошкодити: повинні завжди мати тверезу голову $і$ діяти розсудливо (Ростислав Самбук, «Дияволи з «Веселого пекла»»); ясна голова (дуже розумна людина) - Справжній вчений, ясна голова, провідний прачџівник науково-дослідного інституту, керівник великої теми: експедииія нама відбувалася, власне, тому, що з нами їхав Григорій Михайлович (Анатолій Дімаров, «Вершини»). Решта фразеологізмів із компонентом «голова» описують риси характеру людини: гаряча голова (про запальну людину) - Хто недалекоглядний, у кого гаряча голова - хай ризикує (Роман Іваничук, «Журавлиний крик»); необачна голова (про нерозсудливу, необережну людину) - Захопився був Олефір Голуб переслідуванням пораненого Кантеміра, - та попав необачною головою під шаблюку одного з батирів (Станіслав Тельнюк, «Яром-долиною...»).

Отже, аналіз вищеподаних фразеологічних одиниць засвідчив, що показник соматичного КК «голова» цілком підтверджує своє стереотипне для українців символьне уявлення як утілення розуму, духовного життя, будучи водночас амбівалентним, репрезентуючи собою також людську нерозумність, нетямущість. Знаковими маркерами водночас виступають і атрибути поруч із «головою», які підсилюють, підкреслюють іiі семантику: із прямим, конкретним значенням («дурна», «нерозумна», «порожня», «пуста», «розумна», «необачна») та вторинним, переносним, наділеним символьністю («дубова» < «дуб» - символ нерозважливості; «капустяна» < «капуста», «куряча» < «курка» - символи некмітливості; «золота» < «золото», «світла» < «світло», «твереза» < «тверезість», «ясна» < «ясність» символи обдарованості, розумності, розсудливості; «гаряча» - символ запальності, схильності ризикувати).

Досить продуктивними показниками соматичного КК в антропоцентричній фразеології $є$ образно-мотиваційні лексеми «серце» 
(реалізує такі словникові значення у структурі семантики фразеологізмів, як «орган людини як символ зосередження почуттів, настроїв, переживань і т.ін.», «здатність почувати й розуміти інших; чуйність, сердечність», «сукупність якостей, рис, властивих певній особі; вдача людини», «людина як носій тих чи інших рис, якостей») (живе серие (про небайдужу, здатну проникатися чужими переживаннями людину) - Тому $i$ зла багато на світі, щзо у багатьох людей немає в грудях живого серця, а тільки мертвий камінь (Марія Ільїна, «Кам'яне серце»); золоте серцее (правдива, відверта, доброзичлива, сердечна людина) - Золоте серце: сам нічого не має, а все про других дба! (Михайло Старицький, «Не судилось»); кам'яне серие (про жорстоку, бездушну людину) - Що ж мені робить, коли як живу на світі - в мою залізну душу $і$ кам'яне серце не западало ще жалю до мого ближнього і на макове зернятко! (Олекса Стороженко, «Марко Проклятий»); щуире сериее (про правдиву, відверту, доброзичливу, сердечну людину) - Вони висміяли все це, зрозумівши раз, щуо їх мати погорджує тими речами, котрі, щзоправда, не були самі собою надто вартісні, але цінні тим, щзо їх дарувало щцре серце доброї старушки (Ольга Кобилянська, «Царівна»)); «око» (реалізовані у фразеологічній семантиці словникові значення «орган зору у людини», «погляд»): зле око (недобра, недоброзичлива людина) Будемо берегти його, Щеку, від злого ока, недобрих духів та різної напасті! (Володимир Малик, «Князь Кий»); лихе око (недобра, недоброзичлива людина) - Тодi обходитимуть дитя хворості, не зурочить своїм поглядом лихе око, відьомське чаклування чи потайна змова лиходїв (Раїса Іванченко, «Сіті життя і смерті»); погане око (недобра, недоброзичлива людина) $-<\ldots>$ в якійсь ужитковій речі розгледить, скажімо, античну оберегу, щуо мала оберігати скіфастеповика від злих сил, від поганих очей, від поразки тощзо (Олесь Гончар, «Берег любові»)); «рука» (у розглядуваних фразеологізмах реалізоване таке словникове значення, як «кожна 3 верхніх кінцівок людини як знаряддя діяльності, праці»): золоті руки (майстер своєї справи; вправна, уміла, здібна людина) - Нема на всьому березі замка, якому б ради не дав оцей майстер «золоті руки» (Олесь Гончар, «Бригантина»); надійна рука (людина, на яку можна покластися; вірний помічник) - Мом-чил - мій давній другар, моє око на побережжі, моя надійна рука там < .. > (Володимир Малик, «Посол Урус-Шайтана»); нечиста рука (про безчесну, непорядну людину, здатну красти, шахрувати) - А лихий ворог позавидував йому - одняв землю, закрив своєю нечистою рукою ї̈ милий образ <..> (Панас Мирний, «Хіба ревуть воли, як ясла повні»)). 
Так, «серце» репрезентує таку денотативну інформацію, як опис небайдужості, співчутливості, доброзичливості, сердечності / жорстокості, бездушності (тобто, як і у випадку 3 «головою», цей показник соматичного КК виступає у процесі опису характеру людини амбівалентним, двоїстим), «око» - злостивості, недоброзичливості, «рука» - майстерності, вправності, надійності / безчесності, непорядності, шахрайства (будучи так само амбівалентним показником). Емоційно-оцінна інформація у цьому разі $\epsilon$ прозорою для розуміння, що видно з вищеподаного контекстного уживання: означені фразеологізмами негативні риси людського характеру засуджуються, позитивні - схвалюються. Цікаво, що всі зазначені лексемирепрезентанти соматичного КК виступають символами: узагальнене значення «серця» - здатність людини до емпатії (атрибути водночас підсилюють значення фразеологізму: «живе» < «життя», «золоте» < «золото», «щире» < «щирість» як ознака співчутливості / «кам'яне» < «камінь» як ознака твердості, жорсткості характеру), «ока» злостивість, здатність зурочити (+ «промовисті» атрибути «зле», «лихе», «погане»), «руки» - здатність щось робити руками (+ атрибути «золоті» < «золото» як символ майстерності та талановитості, «надійна» - вірності, «нечиста» - шахрайства). На периферії соматичного КК в антропоцентричній фразеології зафіксовано такі одиниці: сива борода «мудра, з великим життєвим досвідом людина» Старик, сива борода, виходить: «Мабуть, синку, душа болить?» (Василь Барка, «Рай») (образно-мотиваційна інформація - показник «борода» (у семантику фразеологізму вплітається таке словникове значення, як «волосяний покрив на нижній частині обличчя»); денотативна - опис мудрості, досвіду людини, здобутих завдяки віку; емоційно-оцінна - позитивна, схвальна, як демонструє контекстне вживання; «борода» також набуває символьного значення, виступаючи уособленням віку людини та ii мудрості, що підсилюється атрибутом «сива»); тверезий голос «про розсудливу людину» - Ясно: ти єдиний між нас втілюєи тверезий голос розсудку (Олесь Гончар, «Циклон») (образно-мотиваційна інформація - лексема «голос» (з реалізованим прямим словниковим значенням «думка, висловлювання, міркування»); денотативна - опис розсудливості людини, здатності критично мислити й висловлюватися; емоційно-оцінна - як засвідчує контекст, позитивна; «голос» виступає символом, уособленням розсудливої, критичної людини 3 аналітичним складом розуму, що підкреслює ознака «тверезий» < «тверезість»); ходячі мощзі (дуже худа, виснажена, немічна людина) - Hiхто у изих ходячих мощах не пізнав би завзятої до всякої роботи жінки, щуо за іграшки нажинала півтори копи дорідних снопів, иіле літо від рання до смеркання не випускала з чіпких чорних, 
як залізо, пальиів то проворної сапки, то граблів, то серпа (Михайло Стельмах, «Велика рідня») (образно-мотиваційна інформація показник «мощі»; денотативна - опис худорби, виснаженості, немічності людини; емоційно-оцінна - негативна, принизлива, поблажливо-жаліслива, виходячи з контексту; «мощі» являють собою символ пейоративного втілення фізично виснаженої людини, що підкреслює дієприкметник «ходячі», роблячи семантику іменникарепрезентанта ще більш яскравою, адже первинне, образномотиваційне його значення - «висохлі, муміфіковані рештки людини», що «ходити» ніяк не здатні).

\section{3. Зооморфний, антропний, міфологічний коди культури в антропоцентричній фразеології - периферія \\ вторинної семіотичної системи}

Аналізований КК виокремлюваний із назвами «зооморфний» Р. Батсуреном, О. Галинською, М. Ковшовою; «зооморфний (анімальний, теріоморфний)» М. Піменовою; «зоологічний» Т. Леонтьєвою; «біоморфний» (об'єднує зооморфний та фітоморфний КК) Г. Багаутдіновою, Ф. Бацевичем, В. Красних, Л. Савченко, О. Селівановою, І. Токаревою, моделює образи тварин, земноводних, птахів, комах. Найпродуктивнішим показником зооморфного КК виступає лексема «птах» («пташеня»), яка у складі досліджуваних фразеологізмів реалізує таку образно-мотиваційну інформацію (пряме словникове значення), як «людина, яка відзначається чимсь незвичайним, особливим (перев. щодо суспільного стану, значення i т. ін.)». Денотативна інформація зосереджена в мовній семантиці фразеологічних одиниць (опис соціальної значущості, незалежності, нетутешності, досвідченості / недосвідченості), емоційно-оцінна у контекстуальному вираженні (будучи загалом позитивною, з певним відтінком поблажливості, іронічності): важливий пmax (людина, яка займає високе становище в суспільстві і має владу, вагу, великий вплив) - Певно, важллив птахи тамті люди, якщзо їх треба охороняти (Ростислав Самбук, «Бронзовий чорт»); вільний птах (людина, незалежна у своїх вчинках, поведінці) - Tи вільний пmax, знявся й полетів, а мені треба виконувать завдання і рімать питання (Павло Загребельний, «Тисячолітній Миколай»); зальотний птах (нетутешня, прибула звідкись людина) - Потім я дізнався, що він у Черчені зальотний птах, демобілізований прапорщик (Роман Федорів, «Єрусалим на горах»); стріляний птах (досвідчена, бувала людина, яка багато бачила, зазнала) - Вам, полковнику, пальия в рот не клади, та й гер Ангель - стріляний пmax (Ростислав Самбук, «Дияволи 3 «Веселого пекла»»); жовтороте пташеня (молода недосвідчена 
людина) - Це були перші, несміливі спроби стати на крило цілої плеяди жовторотих пташенят, котрі пізніше, пройшовши жорсткий відбір, мали стати хижсии грифами кримінального бізнесу (Юрій Сорока, «Арахнофобія»). Можна стверджувати, що лексема «птах» символізує значущість, свободолюбство, незалежність, непосидючість, досвідченість. Зазначена символьна семантика підкреслюється прозорими для розуміння атрибутами «важливий», «вільний», «зальотний», «жовтороте» та переносним дієприкметником «стріляний» (що символізує набутий досвід). Доволі продуктивними виступають зооморфізми «вівця» («агнець») (образно-мотиваційна інформація - «покірна, ляклива людина», «покірлива, лагідна, сумирна людина»), «вовк» (образно-мотиваційна інформація - «людина, яка багато пережила, загартована життям, витривала»), «горобець» (образно-мотиваційна інформація - «той, хто має великий досвід, кого важко обдурити»). Традиційно денотативна інформація зосереджена в мовній семантиці фразеологічних одиниць (загалом усі вони описують характер людини, сформований життєвими обставинами, умовами тощо): заблукана вівия (людина, яка порвала стосунки 3 тим середовищем, до якого раніше належала, або яка збилася із правильного життєвого шляху) - Мені сказали: ти заблукана вівця, не сповідуєш істин віри, що приписано сповідувати всім, не визнаєш законів, щзо для всіх єдині <...> (Роман Іваничук, «Журавлиний крик»); агнеиь Божий (безвольна, покірлива, розумово обмежена людина) Але я, иінуючи ваш інтелект, подіяла на вас суто інтелектуальними засобами - $i$ от ви лежите, смирна, як агнець Божий! (Павло Загребельний, «Попіл снів») (емоційно-оцінна інформація - значною мірою негативна, зверхня); старий вовк (досвідчена, загартована життям, бувала, витривала людина, яку важко перехитрити, обдурити) - Старий вовк, досвідчений $i$ небезпечний, а все ж припустився помилки: був певен, що відвідини Стецишина лишилися непоміченими (Ростислав Самбук, «Буря на озері»); стріляний вовк (досвідчена, загартована життям, бувала, витривала людина, яку важко перехитрити, обдурити) - Замість убитого горем старого, на стільиі сидів зовсім інший чоловік, той самий стріляний вовк, якого бачив перед собою стариина Гейко в снігових кучугурах, де свистіли кулі (Анатолій Стась, «Сріблясте марево») (емоційно-оцінна інформація однозначно позитивна); старий горобець (досвідчена, загартована життям, бувала, витривала людина, яку важко перехитрити, обдурити) - < ..> старий горобець, на метр під землею бачить, а тут не відрізнив капітана міліиії від звичайного курортника <..> (Ростислав Самбук, «Буря на озері»); стріляний горобець (досвідчена, загартована життям, бувала, витривала людина, яку важко перехитрити, 
обдурити) - Але ви вже, як кажуть росіяни, стріляний горобець $i$ маєте великий досвід у нашій справі (Юрій Дольд-Михайлик, «У чорних лицарів») (емоційно-оцінна інформація - позитивна).

Як засвідчує аналіз, «вівця» виступає символом безвольності й покірливості, слабкості (семантика якого уяскравлена конкретним за значенням дієприкметником «заблукана» та прикметником «Божий» (у сполученні 3 варіантом-церковнослов'янізмом «агнець» набуває однозначного пейоративного забарвлення)), «вовк» i «горобець» символи досвідченості й витривалості (семантика яких підкреслюється конкретним прикметником «старий» i вторинним за значенням дієприкметником «стріляний», який, як було зазначено вище, також символізує значний життєвий досвід).

На периферії зооморфного КК було зафіксовано такі фразеологічні одиниці: підколодна гадюка (підступна, зловмисна людина) У, стерва, гадюка підколодна! (Галина Тарасюк, «Сестра моєї самотності») (образно-мотиваційна інформація - «зла, підступна людина»; денотативна інформація - опис підступності як риси людського характеру; емоційно-оцінна інформація - різко негативна; «гадюка» виступає символом зловмисності, підлості (що підкреслюється конкретним атрибутом «підколодна», що надає символічній семантиці відтінку принизливості)); мокра курка (безвольна, нерішуча, жалюгідна на вигляд людина) - Бачила себе збоку мокра курка в сукні, більше схожій на марлю, що з усіх боків обплутала тіло, ще ци з розкислим бубликом на пальиі! (Ірен Роздобудько, «Якби») (образно-мотиваційна інформація - «жалюгідна, безвольна, нерішуча людина»; денотативна інформація - опис жалюгідності людини; емоційно-оцінна інформація - негативна, зверхня; «курка» символізує людську жалюгідність, слабкість, безвольність (те, що їх помітно й зовні, підкреслює атрибут «мокра»)); старий лис (підступна, лукава людина) - Граф змальовувався в них як старий лис, що намагається під пишною словесною мішурою приховати свою фашистську суть (Юрій Дольд-Михайлик, «І один у полі воїн») (образно-мотиваційна інформація - «хитра, лукава людина»; денотативна інформація - опис підступності як визначальної риси характеру людини; емоційно-оцінна інформація - негативна; «лис» символізує хитрість, підступність, лукавство (конкретний за значенням атрибут «старий» вказує на те, що всі ці якості вдачі людина набуває внаслідок пережитого)); Валаамова ослиця (покірлива, мовчазна людина, що несподівано висловлює протест) - Добре вам говорити про Валаамому ослицю, але коли кожен осел почне вчити свого хазяїна $i$ керувати людськими вчинками за своїм ослячим розумінням, ми самі перетворимось на ослячий табун (Зінаїда Тулуб, 
«Людолови») (образно-мотиваційна інформація - «нерозумна, вперта людина»; денотативна інформація - опис рабської покірливості, терплячості (якій приходить із часом кінець); емоційно-оцінна інформація - негативна, зверхня; «ослиця» виступає символом тупої покірності й терплячості (значення якого увиразнюється церковнослов'янізмом «Валаамова»)); велика риба (впливова людина, поважна особа) - Обережно, прошу тебе, через неї на велику рибу можемо вийти (Ростислав Самбук, «Гіркий дим») (образномотиваційна інформація - «впливова людина»; денотативна інформація - опис впливовості, соціальної значущості людини; емоційно-оцінна інформація - позитивна; «риба» виступає символом впливовості традиційно у сполученні 3 прикметником «велика» (семантика яких зливається в одне)); потайний собака (підступна людина) - Це як потайний собака з-за тину, не знаєш, коли й де вкусить (Павло Загребельний, «Тисячолітній Миколай») (образномотиваційна інформація - «зла, жорстока, недоброзичлива і т. ін. людина»; денотативна інформація - опис підступності як визначальної риси людської вдачі; емоційно-оцінна інформація - різко негативна, зверхня; «собака» - символ злостивості й підлості у сполученні 3 конкретним атрибутом «потайний»); Боже теля (дуже спокійна, лагідна, але безвольна, інертна людина) - Ti садомазохісти Божі телята порівняно з тобою (Марія Матіос, «Чотири пори життя») (образно-мотиваційна інформація - «той, хто має спокійну вдачу; покірний»; денотативна інформація - опис унікального характеру людини, який поєднує лагідність 3 інертністю; емоційно-оцінна інформація - негативна, поблажлива; «теля» - символ покірливості, спокійного, однак безвольного характеру (що увиразнюється церковнослов'янізмом «Божі»)); глуха тетеря (людина, яка погано чує) Глуха тетеря, хіба не чув пострілів? (Владлен Суслов, «На каравелі «Улюбленець Нептуна») (образно-мотиваційна інформація - «глуха, ледача й т.ін. людина»; денотативна інформація - опис особливого фізичного стану людини, яка, користуючись ним, може уникати роботи, відповідальності тощо; емоційно-оцінна інформація негативна, поблажлива; «тетеря» - символ вайлуватості, ледачості (у сполученні з атрибутом «глуха» ще й + глухість як фізична вада)).

Цей КК виокремлюваний як антропний Р. Батсуреном, О. Галинською, Л. Савченко; як антропний (власне людський) О. Селівановою; як антропологічний Т. Леонтьєвою, моделює образи за різними номінаціями людини. В антропоцентричній фразеології показниками антропного КК виступають кілька лексем: 1) «геній»: добрий геній (людина, яка благотворно впливає на кого-небудь, приносить користь комусь) - Як добрий геній, Ганя здержувала 
шкодливий ляхівський вплив Хоцінського (Іван Нечуй-Левицький, «Причепа»); злий геній (про людину, яка погано впливає на когонебудь, приносить шкоду комусь) - Злий геній капіталіста ц̆ експлуататора доктора Гальванеску обертав людей, робітників на неживі ляльки (Юрій Смолич, «Прекрасні катастрофи») (образномотиваційна інформація - «особа, наділена геніальністю», «найвищий вияв, уособлення чого-небудь»; денотативна інформація - опис вдачі людини (доброї, благотворної / злостивої, шкідливої); емоційнооцінна інформація - позитивна / негативна в залежності від контексту; «геній» - символ зразкового вияву чого-небудь (у сполученні 3 конкретними атрибутами «добрий» - людської доброти, «злий» людської злостивості)); 2) «брат»: наш брат (близька думками, переконаннями людина; однодумець) - Тож наші брати, то частки тієї Праєдності, а з'єднатися - не можна! (Олесь Бердник, «Чаша Амріти») (образно-мотиваційна інформація - «близька, своя людина; однодумець, друг»; денотативна інформація - опис близьких зв'язків між людьми; емоційно-оцінна інформація - позитивна; «брат» - символ дружби, вірності, близькості поглядів); 3) «дурень»: безнадійний дурень (дуже обмежена, тупа, недалека людина) - Тільки безнадійний дурень та безнадійний злостивець може радіти війні - отому страшному посіву здичавіння, свинщю $і$ смерті (Михайло Стельмах, «Чотири броди») (образно-мотиваційна інформація - «розумово обмежена, тупа людина»; денотативна інформація - опис нерозвинених розумових здібностей людини; емоційно-оцінна інформація - різко негативна); 4) «людина»: знатна людина (заможна людина, поважна особа) У ивому князеві нічого не було від знатної людини, яка звикла до того, що ї̈ дорогоиінне життя мають оберігати десятки, коли не сотні інших людей (Володимир Рутківський, «Джури і підводний човен») (образно-мотиваційна інформація - «особа», «постать»; денотативна інформація - опис високого соціального статусу людини; емоційнооцінна інформація - позитивна, однак з відтінком зверхності, певної зниженості); 5) «мертвяк»: ходячий мертвяк (людина, що втратила інтерес до життя, байдужа до всього) - Бо нема владики, є ходячий мертвяк, примара колишнього владики (Володимир Винниченко, «Сонячна машина») (образно-мотиваційна інформація - «людина у стані фізичного або духовного занепаду»; денотативна інформація опис пасивності, аморфності, хворобливості людини; емоційно-оцінна інформація - негативна; «мертвяк» символізує цілковитий фізичний, духовний, емоційний тощо занепад людини (що уяскравлено атрибутом «ходячий»)); 6) «труп»: живий труn (людина, позбавлена будь-яких життєвих інтересів, прагнень, бажань, байдужа до всього) - Отож невдовзі упиреня й виїло з чоловіка всю його волю, бо ж людина без волі 
ніколи не помічає, щзо вона живий труп (Емма Андієвська, «Казка про упиреня, що живилося людською волею») (образно-мотиваційна інформація - «мертве тіло людини або тварини»; денотативна інформація - опис пасивності, аморфності, абсолютної байдужості людини; емоційно-оцінна інформація - негативна; «живий труп» виступає символом-оксюмороном, втілюючи цілковиту безініціативність, байдужість, пасивність життєвої позиції людини); 7) «Хома»: Хома невірний (людина, що сумнівається, не вірить у щонебудь) - Дивіться, повірив Хома невірний! (Роман Іваничук, «Бо війна війною...») (образно-мотиваційна інформація - номен, чоловіче ім'я; денотативна інформація - опис надміру недовірливої людини; емоційно-оцінна інформація - негативна, поблажлива; саме ім'я «Хома» постає символом неаргументованої недовірливості (що підсилюється атрибутом «невірний»)).

Аналізований КК моделює образи релігійних i надприродних уявлень, героїв міфів, казок, легенд, літературних творів i виокремлюваний як «міфологічний» Г. Багаутдіновою, Т. Леонтьєвою; як «релігійний» О. Галинською, О. Селівановою. Типовим показником міфологічного КК у фразеологічних одиницях, що описують людину, виступає лексема «душа», яка передає таку образно-мотиваційну інформацію, як «внутрішній психічний світ людини, з ії настроями, переживаннями та почуттями», «безсмертна нематеріальна основа в людині, що становить суть іï життя, $є$ джерелом психічних явищ i відрізняє ï від тварини», «сукупність рис, якостей, властивих певній особі», «людина як носій тих чи інших рис, якостей», «людина 3 прекрасними рисами характеру». Денотативна інформація зосереджена в мовній семантиці проаналізованих фразеологічних одиниць (усі вони описують риси характеру людини, особливості іiі вдачі), а емоційнооцінна - у контексті вживання (загалом позитивна, лише в деяких випадках - 3 певним відтінком зниженості): жива душа (людина) Хоч одна жива душа поставилася до мене по-людськи! Привітала $з$ успіхом! (Марина Гримич, «Варфоломієва ніч»); заяча душа (боязка, полохлива людина) - То боягузи, заячі душі, повидумувані, щзо на кладовищі вночі страшно (Всеволод Нестайко, «Тореадори 3 Васюківки»); золота душа (про правдиву, відверту, доброзичливу, сердечну людину) - Розумієи, який був у нас із Антоном дід, твій прадід Ілля, яку золоту душу мав $і$ яке справді янгольське серие! (Ростислав Самбук, «Скіфська чаша»); пропаща душа (обездолена, занепащена людина) - Я працюю у відділі пропащих душ, підвідділ комівояжерів-душогубів (Юрій Ячейкін, «Химери Зеленого Змія»); хвацька душа (безрозсудно хоробра, відчайдушна людина) - I взагалі <...> смілива, хвацька душа! Одне слово, з живчиком, $з$ перчиком 
хлопець (Олесь Гончар, «Бригантина»); щиира душа (правдива, відверта, доброзичлива, сердечна людина) - Я давно не був у такому теплі й затишку, отеиь Олексій ие знав $i$, щира душа, добряче натопив грубку, зробив усе, аби нам було в нього зручно $i$ затишно (Василь Шкляр, «Чорний ворон»). Безсумнівно, «душа» $\epsilon$ символом - людяності, доброзичливості, сердечності, хоробрості, правдивості / полохливості, обездоленості (що підкреслюється відповідними атрибутами прозорими для розуміння та сприйняття: «жива», «пропаща», «хвацька», «щира» та переносними «заяча» < «заєць» - символ полохливості, боязливості, «золота» < «золото» - символ доброти, відкритості, сердечності).

\section{ВИСНОВКИ}

Фразеологізм - особливий знак мови, що має не тільки мовне значення, але й культурну конотацію. Культурна конотація - ключове поняття лінгвокультурології, під яким розуміють зв'язну ланку між значенням одиниць природної мови та простором культури сформованими в ній стереотипними уявленнями, символами, міфологемами, еталонами тощо. До сприйняття мовної семантики тією або іншою мірою «підключена» культурна семантика у вигляді стійких уявлень, стереотипів тощо. Зміст культурної конотації «добудовує» семантику мовного знака, долає семантичну невизначеність окремих фразеологізмів, пояснює феномен їхньої широкозначності. Для визначення й опису синтезу мовної й культурної семантики використано метод послідовного вичленовування різних типів інформації, репрезентованих студійованими фразеологічними одиницями: образно-мотиваційної (первинне, словникове значення лексеми-показника того чи того коду культури, що лежить в основі творення фразеологізму); денотативної (мовна семантика фразеологізму); емоційно-оцінної (контекст уживання фразеологізму з паралельним визначенням характеру висловлюваної комунікантами оцінки).

Інструментом лінгвокультурологійного студіювання фразеологічних одиниць визначено коди культури - вторинну знакову систему, що структурує, категоризує, оцінює матеріальний і духовний світи людини й репрезентована різними етнокультурно маркованими мовними одиницями (у межах роботи - фразеологізмами). Дослідження показало, що ключовими для опису антропоцентричної субстантивної фразеології постають соматичний (моделює образи частин тіла людини (рідше - тварини) і продуктів іï життєдіяльності) - утворює ядро вторинної семіотичної системи); зооморфний (моделює образи тварин, земноводних, птахів, комах), антропний (моделює образи номінацій 
людини) та міфологічний (моделює образи релігійних і надприродних уявлень, героїв міфів, казок, легенд, літературних творів) - формує периферію вторинної семіотичної системи - коди культури.

Доведено, що образно-мотиваційною базою для творення антропоцентричної фразеології постають такі лексеми-показники кодів культури, як «голова», «серце», «око», «рука», «птах», «вівця», «вовк», «горобець», «геній», «брат», «дурень», «людина», «мертвяк», «труп», «Хома», «душа» та ін. Денотатом зазвичай виступають розумові здібності, риси характеру, соціальний стан людини тощо. Емоційнооцінна характеристика може бути як негативною, так і позитивною (утім, з явною перевагою першої).

\section{АНОТАЦІЯ}

У дослідженні розглянуто проблему взаємозв'язку мови і культури, реалізації культурних смислів засобами фразеологічних одиниць. Як інструмент лінгвокультурологійного опису антропоцентричних субстантивних фразеологізмів використано систему кодів культури. Проаналізовано різні типи інформації, репрезентованої за допомогою культурно значущих фразеологічних одиниць: образно-мотиваційну, денотативну, емоційно-оцінну. Образно-мотиваційна інформація формована за допомогою лексем-репрезентантів того чи того коду культури, денотативна - мовною семантикою фразеологічних одиниць, емоційно-оцінна - контекстом уживання. Ядро проаналізованої вторинної семіотичної системи на матеріалі антропоцентричної субстантивної фразеології утворює соматичний код культури. Периферію дослідженої фразеології формують зооморфний, антропний i міфологічний коди культури. Доведено, що більшість студійованих фразеологізмів набувають символьного значення.

\section{ЛІТЕРАТУРА}

1. Академічний тлумачний словник української мови. URL: http://sum.in.ua/ (дата звернення: 29.04.2020).

2. Бацевич Ф. Словник термінів міжкультурної комунікації. Київ, 2007. 205 c.

3. Березович Е. Язык и традиционная культура: этнолингвистические исследования. Москва, 2007. 600 с.

4. Гудков Д. Единицы кодов культуры: проблемы семантики. Язык. Сознание. Коммуникация. Москва, 2004. Вып. 26. С. 39-50.

5. Ковшова М. Семантика и прагматика фразеологизмов: лингвокультурологический аспект : автореф. дис. ... докт. филол. наук: 10.02.19. Москва, 2009. 48 с. 
6. Красных В. Коды и эталоны культуры (приглашение к разговору). Язык, сознание, коммуникация. Москва, 2001. Вып. 19. C. $5-19$.

7. Красных В. Этнопсихолингвистика и лингвокультурология : курс лекций. Москва, 2002. 284 с.

8. Савченко Л. Феномен етнокодівдуховної культури у фразеології української мови: етимологічний та етнолінгвістичний аспекти. Сімферополь, 2013. 600 с.

9. Селіванова О. Нариси 3 української фразеології (психокогнітивний та етнокультурний аспекти). Київ ; Черкаси, 2004. $276 \mathrm{c}$.

10. Телия В. Русская фразеология. Семантический, прагматический и лингвокультурологический аспекты. Москва, 1996. 286 с.

Information about the author: Harbera I. V.,

Candidate of Philological Sciences, Associate Professor at the Department of General and Applied Linguistics and Slavic Philology Vasyl' Stus Donetsk National University 21, 600-Richchia str., Vinnytsia, 21021, Ukraine 